Eskişehir Osmangazi Üniversitesi Mühendislik ve Mimarlık Fakültesi Dergisi 26(1), 30-35, 2018
The Journal of Engineering and Architecture Faculty of

Eskisehir Osmangazi University 26(1), 30-35, 2018

\title{
STATISTICAL INVESTIGATION OF THE NOISE LEVELS IN COAL MINING INDUSTRY
}

\author{
Seyhan ÖNDER ${ }^{1 *}$, Mustafa ÖNDER ${ }^{2}$ \\ ${ }^{1}$ Department of Mining Engineering, Eskisehir Osmangazi University, Eskisehir, Turkey, sonder@ogu.edu.tr, \\ ORCID No : https://orcid.org/0000-0003-0396-9995 \\ ${ }^{2}$ Department of Mining Engineering, Eskisehir Osmangazi University, Eskisehir, Turkey, monder@ogu.edu.tr, \\ ORCID No : https://orcid.org/0000-0002-9267-1543
}

Makale Geliș : 27.07.2017

Makale Kabul : 13.12.2017

Araştırma Makalesi

\section{Kömür Madenciliği Endüstrisinde Gürültü Emisyon Seviyelerinin İstatistiksel İncelemesi}

\section{Öz}

Madencilikte gürültü maruziyeti ve gürültüye bağlı işitme kaybı yaygındır. Gürültüye bağlı işitme kaybını önlemek ve en aza indirmek için çeşitli maden işlemlerinden kaynaklanan eșdeğer gürültü seviyelerinin "Leq" değerlendirilmesi gerekir. Madenciler arasında mesleki işitme kaybının önlenmesine yönelik uygulamalar yetersiz olduğu için, bölgeye özgü veriler üretmek üzere bir kömür madenciliği alanı seçilmiş ve 2004-2007 yılları arasında gürültü ölçüm örnekleri toplanmıştır. Çalışma, lavvar, açık ocak ve yeraltı madenini içeren üç ana maden alanını kapsamaktadır. Gürültü ölçüm çalışmalarından elde edilen veriler, tek yönlü varyans analizi ve Tukey çoklu karșılaştırma prosedürü kullanılarak değerlendirilmiştir. Analizler Minitab ${ }^{\circledR} 14$ istatistik yazılımı kullanılarak yapılmış ve en yüksek gürültü seviyelerini lavvar tesislerinin ürettiği bulunmuştur. Lavvarda çalışan işçiler, izin verilen sınırların oldukça üstünde gürültüye maruz kalmakta ve dolayısıla gürültüye bağlı işitme kaybı açısından daha fazla risk altındadır.

Anahtar Kelimeler : Gürültü Seviyesi, Madencilik Endüstrisi, ANOVA, Tukey
Article Received : 27.07.2017

Article Accepted: 13.12.2017

Research Article

\section{Statistical Investigation of the Levels of Noise in Coal Mining Industry}

\begin{abstract}
Noise exposure and noise-induced hearing loss are prevalent in mining. Assessment of equivalent sound level "Leq" arise from various mining operations is required to prevent and minimize the noise- induced hearing loss. Because the practices for preventing occupational hearing loss among miners are inadequate, a coal mining area was selected to generate site specific data and collected the noise measurement samples from 2004 to 2007. The study covered the three major mining areas including coal preparation plants, open cast mines, and underground mines. The data obtained from the noise measurement studies were evaluated by using one-way analysis of variance and the Tukey's multiple comparison procedure. The analyses were performed by using Minitab ${ }^{\circledR} 14$ statistical software and it was found that the coal handling plants produced the highest noise levels. Workers engaged in the coal preparation plants have higher noise exposures above the permissible limit and hence these workers are at greater risk of noise-induced hearing loss.
\end{abstract}

Keywords : Noise Level, Mining Industry, ANOVA, Tukey

\section{Introduction}

Noise level in an area near to any mining operation depends on numerous factors. However, the most important criterion for estimating the environmental noise is to evaluate the sound power level of the noise sources (Pathak et al. 1999). The coal industry has higher noise levels than the established limits for occupational noise exposure and excessive levels of noise are encountered due to the large machinery operating. The continuous exposure of the workers to such high noise levels can cause noise-induced hearing loss (Sharma et al. 1998 ; Sensogut and Cinar 2007). Workers exposed to noise levels above $82 \mathrm{~dB}(\mathrm{~A})$ are at risk for noise-induced hearing loss, and those exposed to levels above $90 \mathrm{~dB}(\mathrm{~A})$ are at high risk (Phillips et al. 2007).

The noise-induced hearing loss is one of the most

\footnotetext{
${ }^{*}$ Corresponding author; Tel : 0.222.239 3750 / 3423
} 
common occupational disease and particularly severe in all areas of mining (surface, processing plants, and underground) (Vipperman et al. 2007). Because the practices for preventing occupational hearing loss among miners are inadequate (Bauer et al. 2006), in this study, a statistical investigation was conducted to assess the Equivalent Sound Level created by the various coal mining activities. The study covers the three major mining areas such as coal preparation plants, open cast mines, and underground mines. In the present investigation, one-way ANOVA and the Tukey's comparisons procedure were used and statistical analyses were performed by using Minitab ${ }^{\circledR} 14$ statistical software.

\section{Statistical Method}

The technique of analysis of variance (ANOVA) was applied to noise measurement data obtained from the different mining areas. ANOVA is the name given to the approach that allows using sample data to test whether the values of two or more unknown population means are likely to be equal (Sanders 1990).

The object of the investigation is to establish whether or not the different factor levels lead to significant different responses. As usual the null hypothesis is one of no difference between the levels whereas the alternative hypothesis is that at least some of them differ. One-way analysis of variance tests the equality of population means when classification is by one variable. The classification variable usually has three or more levels where the level represents the treatment applied (Stoodley et al. 1980; Minitab 2005).

A one-way classification is used to investigate the effect of one factor which occurs at h levels. In analysis of variance for one-way classification, if the factor levels under consideration are to be regarded as a random sample from a larger number of possible levels then the random model should be used. The model can be given as follows (Stoodley et al. 1980).

$y_{i j}=\mu+\alpha_{i}+\varepsilon_{i j} \quad j=1, \ldots . ., n_{i} ; i=1, . ., h$

Where ;

$\mathrm{y}_{\mathrm{ij}} \quad$ : the $j$ th response when the factor is at level $\mathrm{i}$,

$n_{i} \quad$ : the number of units allocated to level $i$,

$\mu \quad$ : the overall mean,

$\alpha_{i} \quad$ : the deviation from the overall mean at level i,

$\varepsilon_{\mathrm{ij}} \quad:$ the random error term.
The data necessary for this study were collected from the Western Lignite Corporation (WLC) which is located on the mid-west of Turkey. This study was performed in consideration of the results of the official measurement provided by the enterprise. WLC is an important lignite producing company. The coals produced from both open and underground mines of WLC are enriched in coal preparation plants. Noise measurements were made at the most critical location of the mining areas. In the open pit mines of WLC, mining activities include overburden stripping and coal winning. For the overburden removal, an excavator, truck and dragline are employed whereas, for coal winning, a hydraulic excavator and truck combination is used (Sensogut and Cinar 2007). Noise levels of the draglines, trucks, excavators, dozers and drilling machines were investigated at the surface coal mines. The currently applied methods in underground mines are the fully mechanized retreating longwall mining method, and longwall caving and wholly manual. The main ventilation methods in the mines are the exhausting system. In order to investigate the noise levels in the underground coal mines were concentrated on the compressors, fans, monorails, band conveyor ends, conveyor drive systems and other underground mining equipments. Nearly all coal preparation plants employ the same basic coal cleaning processes (Vipperman et al. 2007) and the number of floors in each plant varied from 5 to 12 (Bauer et al. 2006). In the coal preparation plants of WLC, cleaning processes include screening, separation, and dewatering (drying) and specific equipment used to separate the clean coal and waste is the heavy media vessels. At the coal preparation plants, sound level measurements were made in the control rooms, on the all plant floors, and beside the specific equipments in the plants.

The noise measurements data belong to the years 2004 to 2007 were investigated to evaluate the noise emission levels. The sampling areas have been classified such as coal preparation plants, open cast mines, and underground mines. The noise emission levels were determined by TES-1350 digital sound level meter. The maximum action value for noise in the workplace is 85 $\mathrm{dB}(\mathrm{A})$ and the exposure limit value is $87 \mathrm{~dB}(\mathrm{~A})$ (www.resmigazete.gov.tr). Noise measurement data obtained from TES-1350 digital sound level meter at the different mining areas were combined and then, this dataset was used to assess the noise emission levels of different mining areas. The number, mean, range, and standard deviation of noise measurements were determined for each of the different mining areas. These are given in Table 1.

\section{Data Analysis}


Table 1. Mean noise levels $(\mathrm{dB}(\mathrm{A}))$ of the different mining areas

\begin{tabular}{|c|c|c|c|c|c|c|c|c|c|c|c|c|}
\hline \multirow{3}{*}{ Mine Type } & \multicolumn{8}{|c|}{ Years } & \multirow{3}{*}{$\mathrm{N}$} & \multirow{3}{*}{ Mean } & \multirow{3}{*}{ Range } & \multirow{3}{*}{ SD } \\
\hline & \multicolumn{2}{|c|}{2004} & \multicolumn{2}{|c|}{2005} & \multicolumn{2}{|c|}{2006} & \multicolumn{2}{|c|}{2007} & & & & \\
\hline & Mean & SD & Mean & SD & Mean & SD & Mean & SD & & & & \\
\hline Underground & 81.07 & 5.37 & 80.14 & 5.96 & 78.5 & 6.34 & 78.71 & 6.16 & 56 & 79.605 & $64-88$ & 5.901 \\
\hline Open cast & 79.6 & 7.4 & 81.5 & 6.92 & 77.8 & 3.7 & 77.1 & 4.3 & 40 & 79 & $70-89$ & 5.84 \\
\hline $\begin{array}{l}\text { Preparation } \\
\text { plant }\end{array}$ & 91.21 & 1.31 & 90.36 & 1.77 & 85.28 & 3.87 & 85.21 & 4.06 & 56 & 88.018 & $80-94$ & 4.056 \\
\hline
\end{tabular}

$\mathrm{N}$ : Number of samples; SD: Standard deviation

Table 1 shows the noise levels of the three major mining areas. For the dataset given in Table 1, an investigated was conducted to determine whether these results indicate a significant variation between the mining areas. In order to make simultaneous comparisons between the mean values and determine whether a significant relation exists between variables the oneway ANOVA was used. The analyses were performed using Minitab ${ }^{\circledR} 14$ statistical software.

The one-way model analysis of variance assumes that the observations are normally and independently distributed with the same variance for each treatment or factor level. In Minitab there are two ways of conducting a normality test. The normality assumption can be checked by using the Anderson-Darling Normality Test or constructing a normal probability plot of the residuals. For the completely randomized design, each residual is the difference between an observation and the corresponding observed treatment mean (Montgomery and Runger 1999). The Anderson-Darling Normality Test and normal probability plot of the residuals were created. Results are shown in Figure 1a and Figure $1 \mathrm{~b}$.

The mean of the noise measurement data is 82.208 (95\% confidence intervals of 79.175 and 85.240 ). The standard deviation is 4.772 (95\% confidence intervals of 3.381 and 8.103). Using a significance level of 0.05 , the Anderson-Darling Normality Test (A-Squared $=0.66$, $\mathrm{P}-$ Value $=0.064$ ) indicates that the noise measurement data follow a normal distribution (Figure 1(a)). The percentage cumulative frequencies were plotted against the ranked residuals as shown in Figure 1(b). From this graph, it was confirmed that the values were scattered about a straight line, supporting the assumption that the observations were normally distributed (Stoodley et al. 1980).

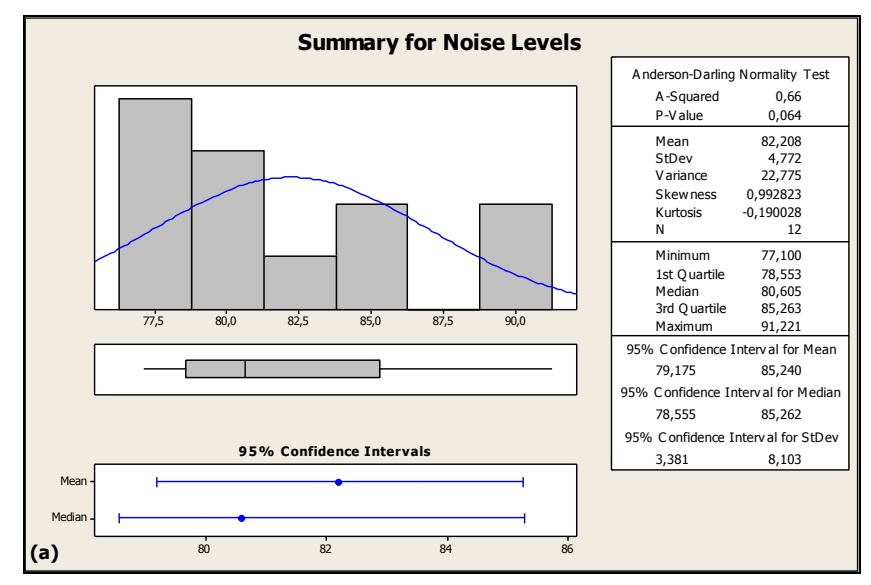

a. The Anderson-Darling Normality Test

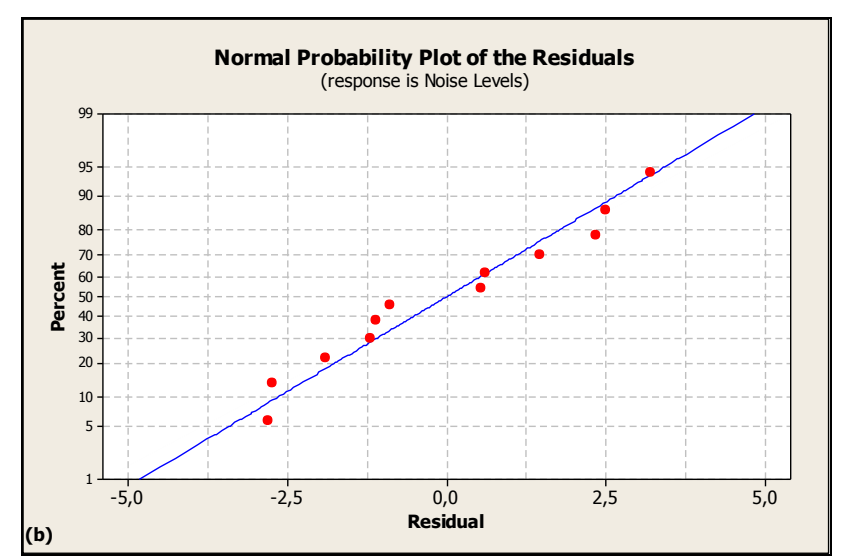

b. Normal probability plot of the residuals

Figure 1. Normality Test

Many statistical procedures, including analysis of variance, assume that although different samples may come from populations with different means, they have the same variance. Minitab calculates and displays a test statistic and p-value for both Bartlett's test and Levene's test where the null hypothesis is of equal variances versus the alternative of not all variances being equal. Bartlett's test is used when the data come from normal distributions and also is not robust to departures from 
normality (Minitab 2005). The variance test procedure was used to test the validity of the equal variance assumption. Results are shown in Figure 2.

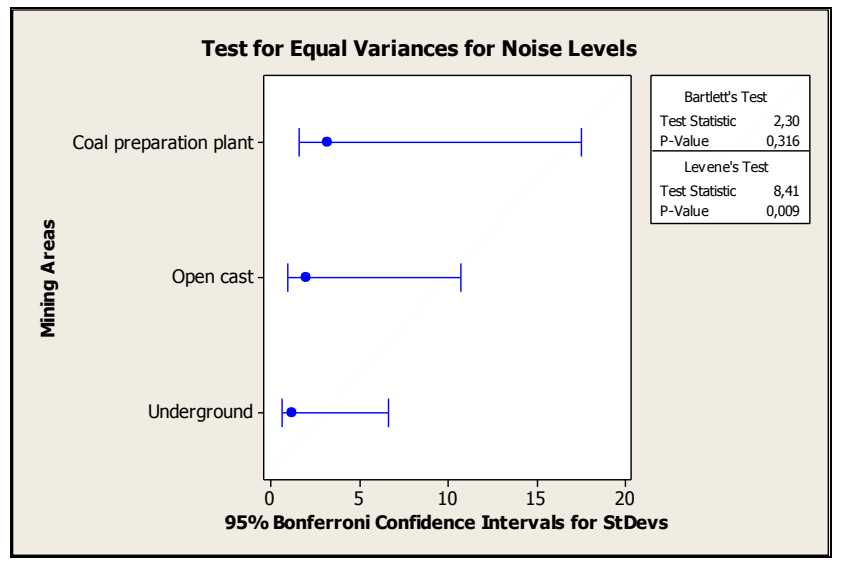

Figure 2. Test for equal variances for noise levels

The test for equal variances generates a plot that displays Bonferroni 95\% confidence intervals for the response standard deviation at each level. Bartlett's and Levene's test results are displayed in both the Session window and in the graph (Minitab 2005). For the mining areas, the Bartlett's test p-value of 0.316 is greater than reasonable choices of $\alpha$. Therefore, we cannot reject the null hypothesis of the variances being equal. That is, these data do not provide enough evidence to claim that the populations have unequal variances.

Interactions plot creates a single interaction plot for two factors. An interactions plot is a plot of means for each level of a factor with the level of a second factor held constant. Interaction is present when the response at a factor level depends upon the level(s) of other factors. Parallel lines in an interactions plot indicate no interaction. The greater the departure of the lines from the parallel state, the higher the degree of interaction (Minitab 2005). In order to judge the presence of interaction, interactions plots were created. These are shown in Figure 3.

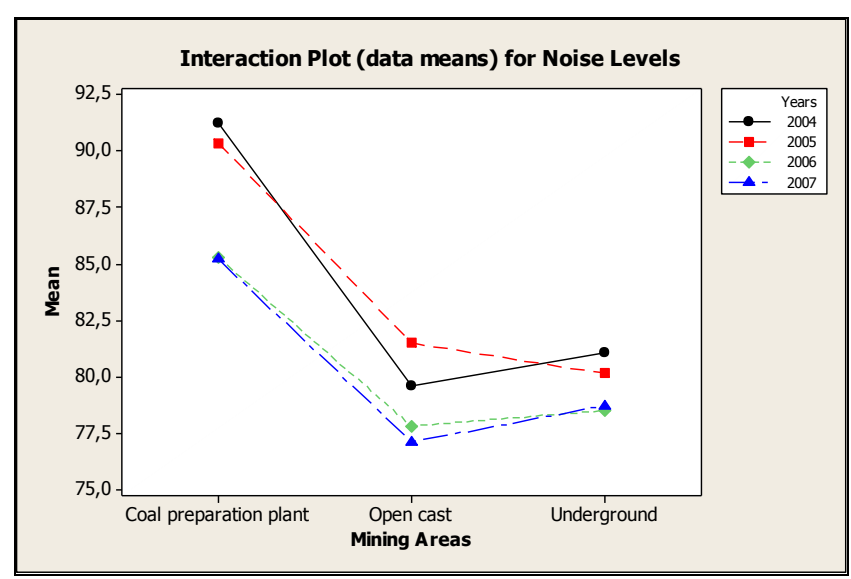

Figure 3. Interaction plot for noise levels
This interaction plot shows the mean noise levels versus the mining areas for each year. This plot shows apparent interaction because the lines are not parallel, implying that the effect of mining areas upon noise levels depends upon the year.

The general format of output for this type of analysis is an ANOVA table, which contains basic information about the analysis. The obtained results are given in Table 2 .

Table 2. One-way ANOVA table for the noise levels

\begin{tabular}{|l|c|c|c|c|}
\hline $\begin{array}{l}\text { Source of } \\
\text { Variation }\end{array}$ & $\begin{array}{c}\text { Sum of } \\
\text { Squares }\end{array}$ & $\mathrm{df}$ & $\begin{array}{c}\text { Mean } \\
\text { Squares }\end{array}$ & $\mathrm{F}$ \\
\hline $\begin{array}{l}\text { Mining } \\
\text { areas }\end{array}$ & 203.28 & 2 & 101.64 & 19.36 \\
\hline Error & 47.24 & 9 & 5.25 & \\
\hline Total & 250.52 & 11 & & \\
\hline
\end{tabular}

Since the purpose of this analysis is to determine if there is a significant difference in the effects of the mining areas, the following hypothesis can be written for the mining area factors;

$$
\begin{aligned}
& H_{0}: \alpha_{1}=\alpha_{2}=\alpha_{3}=0 \\
& H_{1}: \alpha_{1} \neq \alpha_{2} \neq \alpha_{3} \neq 0
\end{aligned}
$$

As usual, the null hypothesis is one of no difference between the levels whereas the alternative hypothesis is that at least some of them differ (Stoodley et al. 1980). From the F-distribution table, the critical value F0.95 (2, 9 ) is 4.26. Since the calculated F-value is greater than the critical value, then the null hypothesis of no difference between the levels of mining area factors is rejected and the alternative hypothesis is accepted. Therefore, it can be said that there is a difference in the mining area level treatments at a significance of $\alpha=5 \%$ level between 2004 and 2007 years. In this stage, the object of the investigation is to determine which of the mining area has the higher noise level. If the null hypothesis is rejected, the Tukey Multiple Comparisons procedure can be used to determine which population means have statistically significant differences from the others and compare all means of groups simultaneously.

In the ANOVA table, the F-value (19.36) for mining areas indicates that there is sufficient evidence that not all the means are equal when alpha is set at 0.05 . To explore the differences among the means, it should be examined the multiple comparison results. Tukey's test provided two sets of multiple comparison confidence intervals and the results were shown in Table 3. 
Table 3. The Tukey multiple comparisons

\begin{tabular}{|c|c|c|c|c|}
\hline \multirow{2}{*}{\multicolumn{2}{|c|}{ Mining Areas }} & \multicolumn{3}{|c|}{ Confidence Intervals } \\
\hline & & Lower & Center & Upper \\
\hline \multirow{2}{*}{$\begin{array}{l}\text { Coal } \\
\text { preparation } \\
\text { plant } \\
\text { subtracted } \\
\text { from }\end{array}$} & Open cast & -13.543 & -9.018 & -4.493 \\
\hline & Underground & -12.938 & -8.413 & -3.888 \\
\hline $\begin{array}{l}\text { Open cast } \\
\text { subtracted } \\
\text { from }\end{array}$ & Underground & -3.92 & 0.605 & 5.13 \\
\hline
\end{tabular}

In the first set of the Tukey's output, coal preparation plant mean subtracted from the open cast and underground means. The first interval $(-13.543,-9.018,-$ 4.493) gives the confidence interval for the coal preparation plant mean subtracted from the open cast mean. For this set of comparisons, the means for coal preparation plant and open cast are statistically different because the confidence interval for this combination of means excludes zero. Similarly, the means for coal preparation plant and underground are statistically different. In the second set of the Tukey's output, open cast and underground are not statistically different because the confidence interval for this combination of means $(-3.92,0.605,5.13)$ includes 0 .

The Tukey multiple comparison procedures showed that there were significant differences between coal preparation plant to open cast and underground mining areas at $5 \%$ level of significance. No significant differences were revealed between the open cast and underground mining areas. In order to examine the overall noise levels of the three mining areas, it was created interval plots (Figure 4). An interval plot illustrates both a measure of central tendency and variability of the data.

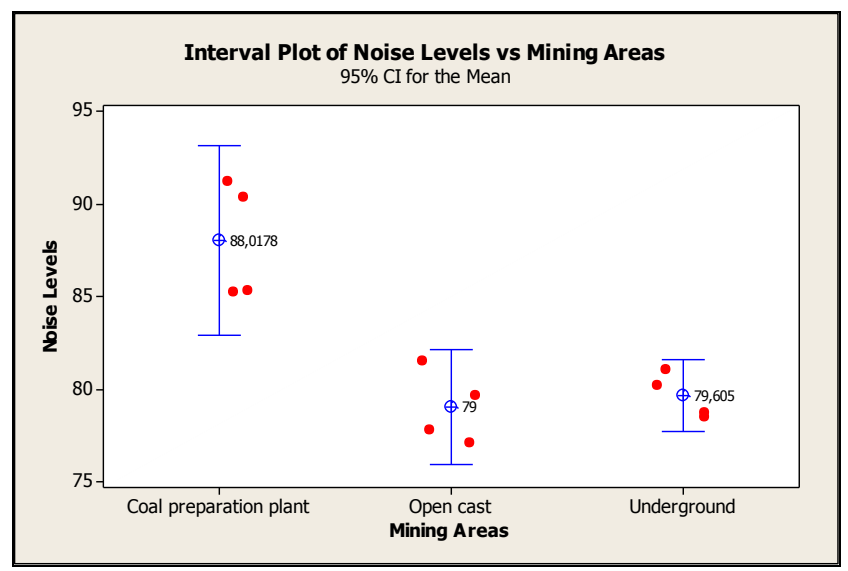

Figure 4. Interval plot of noise levels versus mining areas
Coal preparation plant has the highest mean value of 88.0178 $\mathrm{dB}(\mathrm{A})$, followed by underground (79.605 $\mathrm{dB}(\mathrm{A})$ ) and open cast $(79 \mathrm{~dB}(\mathrm{~A}))$. The intervals all overlap except for coal preparation plant, so we can conclude that the noise levels of the other mining areas except for coal preparation plant are not different.

\section{Conclusions}

The objective of this study was to investigate noise levels for the three major mining areas such as coal preparation plants, open cast mines, and underground mines. According to the available dataset of noise levels for the mining areas and statistical analyses achieved using the Minitab ${ }^{\circledR} 14$ statistical software, it can be said that the coal preparation plants have the higher noise levels. The other noise-producing units can be put in order as underground coal mines and open cast coal mines. The noise levels of the mining areas except for coal preparation plants are not different. The mean noise level of the coal preparation plants found above the prescribed standard of $87 \mathrm{~dB}(\mathrm{~A})$ and over exposures to noise can cause noise-induced hearing loss. In order to reduce the noise level, modification, maintenance or replacement of noisy machines and acoustic isolation can be used. Assessment of the noise levels of mining areas will enable to control the risk of noise-induced hearing loss among workers.

\section{Acknowledgement}

The authors thank to the management of Western Lignite Corporation.

\section{Conflict of Interest}

No conflict of interest was declared by the authors.

\section{References}

Bauer, E.R., Babich, D.R. and Vipperman, J.R. (2006). Equipment Noise and Worker Exposure in the Coal Mining Industry. http://www.safetyshare.org/ documents/niosh_worker_exposure.pdf Accessed 17 July 2017

Minitab, (2005). Analysis of Variance. Minitab 14 Helpto-Go Files. http://www.minitab.com/ support/ docs/rel14/14helpfiles/Statistics/AnalysisofVarian ce.pdf. Accessed 19 November 2007

Montgomery, D.C. and Runger, G.C., (1999). Applied Statistics and Probability for Engineers, John Wiley \& Sons, Inc., New York.

Pathak, K., Durucan, S. and Kunimatsu, S. (1999). Activity Accounting Technique for Environmental 
Eskişehir Osmangazi Üniversitesi Mühendislik ve Mimarlık Fakültesi Dergisi 26(1), 30-35, 2018

Noise Assessment in Mechanized Surface Mining. Environmental Monitoring and Assessment, 56, 241256

Phillips, J. I., Heyns P.S. and Nelson, G. (2007). Rock Drills Used in South African Mines: A Comparative Study of Noise and Vibration Levels. Ann. Occup. Hyg., 51(3), 305-310

Sanders, D.H. (1990), Statistics a Fresh Approach, McGraw-Hill., New York.

Sensogut, C. and Cinar, I. (2007). An Empirical Model for The Noise Propagation in Open Cast Mines - A Case Study. Applied Acoustics, 68(9), 1026-1035

Sharma, O., Mohanan V. and Singh, M. (1998). Noise Emission Levels in Coal Industry. Applied Acoustics, 54 (1), 1-7.

Stoodley, K.D.C., Lewis, T. and Stainton, C.L.S. (1980), Applied Statistical Techniques, Ellis Horwood Limited, England.

Vipperman, J.S., Bauer E.R. and Babich, D.R. (2007). Survey of Noise in Coal Preparation Plants. Journal of the Acoustical Society of America, 121(1), 197-205

www.resmigazete.gov.tr 